\title{
The Relation of Contemporary Labour Market Skills and the Future Engineers' Visions
}

\section{Cs. M. Szabó and O. Bartal}

University of Dunaújváros, Hungary, 2400, Dunaújváros, street Táncsics M., 1/A.

\section{Abstract}

The study describes a segment of an international research which was aimed to find answers what the future generations' (Gen Z) vision is concerning their career and the correlation between these visions and the expectations of labour market nowadays. The preferred competencies of the labour market are constantly altering: a prognosis from 2018 says that the five most important skills will be analytical thinking, innovation, active learning, creativity, and critical thinking in 2022.

Keywords: career, competences, engineering education, future priorities, generation Z, labour market, STEM, top skills

Corresponding Author:

Cs. M. Szabó

szabocs@uniduna.hu

Received: 5 March 2020

Accepted: 18 March 2020

Published: 8 April 2020

Publishing services provided by Knowledge E

(c) Cs. M. Szabó and O.

Bartal. This article is distributed under the terms of the Creative Commons Attribution License, which permits unrestricted use and redistribution provided that the original author and source are credited.

Selection and Peer-review under the responsibility of the SEC 2019 Conference Committee.
G OPEN ACCESS

\section{Introduction}

In the $21^{\text {st }}$ century, not only the economy but the labour market and the society is also changing. Moreover, the education has been altering a lot in the latest years so that it could keep pace with the impacts coming from the partners or from the field of technology. The education is greatly effected by the different segments of society and we can see a phenomenon that the scene of education is becoming multi-level and multi-actor. [Racsko, p. 9.] Higher education institutions need to be aware of the fact that the pedagogical paradigm-shift is required. Firstly, the students entering the gates of the universities are completely different from the students of earlier times. Secondly, the era of digital world is effecting the educators with a much-highlighted impact. Thirdly, the needs and expectations of the labour market are also undergoing a cultural change in their work force and habits. The mission of the universities of present days is the following: educating, research, and the effective social and economical usage of substance of knowledge.

The visions and attitude of generation $\mathbf{Z}$ are completely different from that of the previous generations not to mention their values of life and the priorities they set to themselves. The problem solving methods they use and multitasking operation are just two of the features the would-be engineers have and use during their studies and fulfilment of the tasks. They want to be independent faster than their X parents did, they 
saw them struggling and saving money for everything. Their attitude towards money motivation is merely different from the previous generations. Gen Z members want to gain money to be independent as much as they can, they want to do what is most fulfilling for themselves as individuals. [Brady, 2019] Therefore, we have to accept that the Gen Zers' [Brady] values, norms and life aims are in a different path. That is why both the educational institutions and the students' future employers need to examine this phenomenon and need to adjust the mechanism to it.

According to the World Economic Forum in 2016 held in Davos, Switzerland, the 10 TOP Skills were stated which are needed to be able to obtain a competitive job in 2020. Hereby, we would just make a short comparison with the list of skills stated in 2015. Complex problem solving is still at the first place. Critical thinking and Creativity reached a higher position $\left(2^{\text {nd }}\right.$ and $3^{\text {rd }}$ ) while Cooperation with others became not as substantial as it was in 2015 ( $5^{\text {th }}$ place). Not surprisingly, Emotional intelligence and Cognitive flexibility are on the board $\left(6^{\text {th }}\right.$ and $\left.10^{\text {th }}\right)$ as new factors. The latter ones will be required not just in work places but in the whole society as well. In conclusion, the nature of transformation depends very much on the industry and economy, but the change will not wait for educators, institutions, governments or any leaders, all the actors need to adjust and must be proactive in training and up-skilling would-be-employees attending universities these days.

The knowledge that is given for the engineering students during their university education is really important concerning their future career and professional development. According to the article of Nooan (2017), science, technology, engineering and mathematics (STEM) workers are vital in the field of economy and industry. Nooan states that future engineers are generating new ideas and companies for their country. One of the benefits of the STEM studies is that this is easy to be transferred into various careers, mostly management occupations, especially due to the fact that these studies include handling non-repetitive challenges and that is why, for instance, critical thinking and technical skills are inevitable during the engineering education. It can be seen that the employment and wages in the STEM areas are growing constantly and faster than in non-STEM occupations. [Nooan and Langdon et.al.] According to the mentioned report, the unemployment rate amongst STEM workers is much lower than amongst non-STEM workers. In conclusion, being an engineer student has a lot of advantages for the future career and employment status [Nooan, 2017] not to mention the social mobility from a non-advantageous socio economic status [Wang]. The demand for STEM graduates are raising in all part of the world and it must be admitted that they enjoy higher earnings [Langdon et. al.]. 


\section{Results and Discussions}

The research was conducted by a self-administered questionnaire in spring 2019 among engineer students at two universities: Ural Federal University (URFU - Ekaterinburg, Russia) and the University of Dunaújváros (UOD - Dunaújváros, Hungary). While Russian students filled in a digital questionnaire, Hungarian students answered the questions on paper. All the results were converted into one file and then analysed by the statistical program SPSS 22

The research was a pilot one as the number of the sample is not too big, altogether 117 students, consisting of 64 Hungarian and 53 Russian students. Regarding gender distribution, in the Russian subsample, there are nearly as many boys as girls (males: $52.8 \%$, females: $47.2 \%$, while in the Hungarian subsample, most of the respondents (90.6\%) were males. This refers to the attitude of Hungarian society towards STEM majors and careers: the general idea is still that STEM majors and jobs suit perfectly men.

Students take into consideration several different factors when they choose a university for higher education. There are many differences between Russian and Hungarian students' priorities: while $66 \%$ of Russian students think that the prestige of the university is very important, only $45 \%$ of Hungarian students think the same. Nearly three forth (73.4\%) of Hungarian students consider that the factor after taking the degree it is easy to find a good and well-paid job is really significant; while $53 \%$ of Russian students agree with it. On the other hand, less than $10 \%$ of Russian students chose the university on the basis of the fact that their relatives studied there; while this factor was very important to $25 \%$ of Hungarian students. Analyzing the difference between Russian and Hungarian students by crosstable, five factors show significant difference: the prestige of the university $\left(\chi^{2}=7.855 ; p<0.05\right)$, costs of the training $\left(\chi^{2}=10.329 ; p<0.01\right)$, after taking the degree it is easy to find a job $\left(\chi^{2}=10.001 ; p<0.01\right)$, some privileges in admission $\left(\chi^{2}=7.486 ; p<0.05\right)$, and good vocational training $\left(\chi^{2}=8.511 ; p<0.05\right)$. While the factors prestige of the university and privileges in admission were significantly more important to Russian students, much more Hungarian students prioritized the factors costs of training and easy to find a job. Although more Hungarian than Russian students considered that a good vocational training is very important, the difference is not essential, only $9 \%$. However, more than twice more Russian students (41.5\%) answered that it is hard to say than Hungarian ones (18.8\%). It seems that Hungarian students are more decided about practical training. 
Nowadays, many university students have a kind of work experience before their higher education studies. There are several reasons in the background of this phenomenon, such as earn money, start a job after technical secondary education, etc. According to the results, this tendency is more popular among Hungarian students: $39 \%$ of them have had a little work experience before going to university, while less than $6 \%$ of Russian students worked before the university. On the other hand, more than $60 \%$ of Russians answered they had no idea at all about their future career, while $26.6 \%$ of Hungarian students mentioned that.

The training: the subjects, the tasks, the teachers, and the practices and the internship have an influence on students' attitude towards their studies and future career, and might change their ideas about the major. Most Hungarian students (42.2\%) answered they their ideas had not changed at all, and only $25 \%$ of them replied that their attitude had changed for better. On the contrary, majority of Russian students' (52.8\%) opinion about their future job became better, and only 7.5\% of them answered and their ideas had not changed at all. As the majority of Russian students (60\%) had no idea about their major when they started their university studies, half of the students have changed their opinion during the training and think more positively. However, there is no significant correlation between previous ideas and opinion changes either in the Russian or in the Hungarian subsamples.

The prestige of STEM jobs, such as engineering are highly evaluated and well-paid in all developed societies. This social attitude is clearly mirrored in students' opinion: both Hungarian and Russian students consider the prestige of engineer or IT career very high - and not only in present but in the near past and near future too. On the five-grade Likert-scale, the lowest mean was 4.15 (today prestige by Russian students), while the highest mean was 4.55 (future prestige by the Russians). According to the Hungarian students' opinion, there is very little difference between the engineering and IT job prestige in the past, present and future.

Although students agree that the prestige of engineering and IT careers is rather high, they are not totally sure whether it is easy to find a job with an engineer degree: the average of the answers is 3.5, and the deviation is big (1.649). Comparing the answers of Russian and Hungarian students, it could be stated that Hungarian students are much more confident: more than half of them (51.6\%) believe that it is easy to find a good and well-paid job; on the other hand, only $28 \%$ of Russian students think the same. On the other hand, forth more Russian (13.2\%) than Hungarian (3.1\%) students think that it is almost impossible to find a job in the city with an engineer degree. Moreover, much more Russian (34\%) than Hungarian (20.3\%) students think it is hard to say. 
There are medium strong positive significant correlations between the variables finding a job with an engineer degree and the prestige of engineer job in the past $(r=0.295 ; p<0.01)$, in the present $(r=0.338 ; p<0.001)$ and in the future $(r=0.196 ; p<0.05)$. Comparing the results based on the nationalities, in the Hungarian subsample finding a job correlates with job prestige in the present $(r=0.306 ; p<0.05)$ and future $(r=0.306$; $p<0.05)$, while in the Russian subsample with job prestige in the past $(r=0.334 ; p<0.05)$ and present $(r=0.338 ; p<0.05)$.

Since students assume the prestige of engineer job high, and most of them see they will easily find a good and well-paid or minimum any kind of job after taking their degree, they did not regret choosing this career. On a five-grade Likert-scale, the mean of their evaluation is 1.59 , which means half way in between they did not regret at all and generally they did not regret but they want another profession (too). $65 \%$ answered that had not regretted at all and another $20.5 \%$ said that although they generally had not regretted but they wanted another profession (too). Only 3.4\% concluded that they had regretted because this job was not theirs and the same proportion supposed that they would learn another profession and work in the new job. There was very little difference between the two national subsamples.

Reviewing students' opinion on future priorities, it clearly can be seen that they belong to gen Z: majority of students find very important the factors that refer to enjoying their jobs and a calm, work-life balanced way of living. They consider it very important that they could do what really interests them (88.9\%) and use their abilities and talents $(82,1 \%)$. On the other hand, majority indicated that the good work atmosphere $(88 \%)$ and the balance of work and private life (83.8\%) was very important. Factors that are absolutely not important to students refer to social commitment and job safety: $28.2 \%$ answered that it was not important to do a job that was beneficial for society and to have a regular job with firm but low salary. Due to the fact that Zers have seen their parents struggle as entrepreneurs, $42 \%$ declared that they do not want to have their own business.

However, there are differences between Russian and Hungarian students; Figure 1 shows the differences. More Russian students reported very important to do something that interests them (94.3\%), to be able to use their abilities (90.6\%), to have good work atmosphere (92.5\%), and to have work-life balance (86.8\%). Moreover, Russian students are more willing to launch their own business (37.7\%). On the other hand, nearly half of the Russian students regarded very important to have a safe, steady but not well-paid job in the future (45.3\%). On the contrary, for Hungarian students the most important 
factors are to do a job according to their profession (76.6\%) and high financial rewards (75\%).

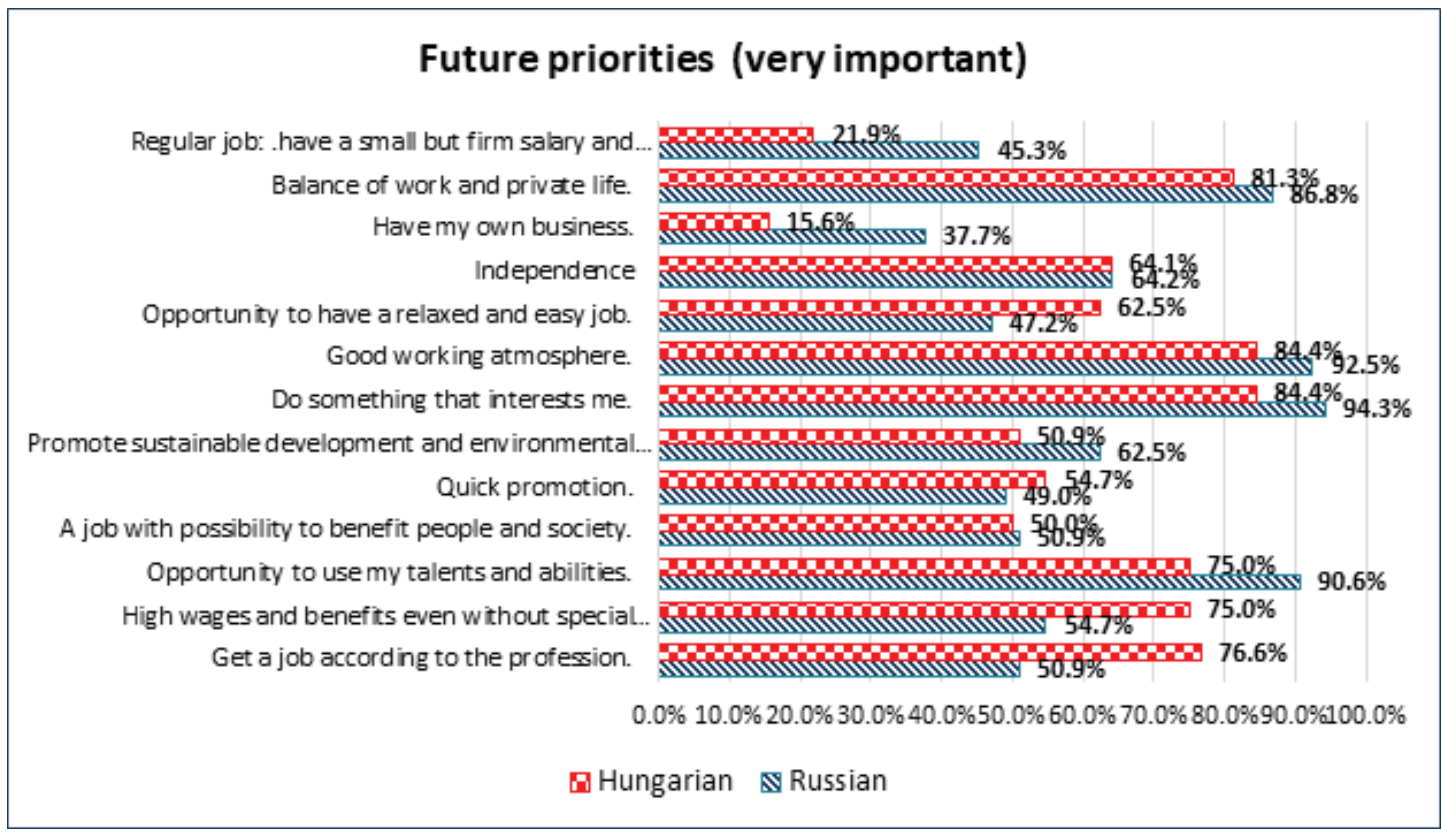

Figure 1: Future priorities - comparison of the Russian and Hungarian students

Examining the difference between Russian and Hungarian students' opinion, we have found six variables where the difference was significant. The factors to do a job based on my degree $\left(\chi^{2}=9.547 ; p<0.01\right)$ and to gain high wages and benefits $\left(\chi^{2}=8.494 ; p<0.05\right)$ were significantly more important to Hungarian students. As for Russian students, they found significantly more important that they could use their abilities and talents $\left(\chi^{2}=8.653 ; p<0.05\right)$, have their own business $\left(\chi^{2}=8.677 ; p<0.05\right)$ and find a regular, safe but not well-paid job $\left(\chi^{2}=9.212 ; p<0.01\right)$. Moreover, there was a significant difference regarding the variable quick promotion $\left(\chi^{2}=7.158 ; p<0.05\right)$. Although there was not too much difference between the Russian and Hungarian figure perceiving this factor very important (Russian: 49.1\%, Hungarian: 55.6\%), almost twice more Hungarian student did not regard it important but twice Russian students could not decide the significance of this factor.

\section{Conclusions}

The most highlighted progressions for any society in the world are coming from those who have studied at the field of STEM. The competitiveness in economy and industry, the overall standard of living or even the growth of a nation greatly depend on the workforce belonging to engineers, in a wider meaning to STEM graduates. [Langdon et. 
al.] Although Russian and Hungarian students prioritized different factors of choosing the university, the fact that they were interested in science and mathematics was significant for both nations. Despite the difficulties of learning and understanding sciences, majority of students did not regret their choice and most of their ideas either did not change about their future job or became more positive. They assess the prestige of the engineering career very high and as a consequence most of them believe they it will be easy to find a good job after taking the degree.

Regarding their future priorities, the most important factors are to do in their future jobs what they really like doing, able to use their skills and talents, work in a good atmosphere, have work and private life balance. These factors are especially significant for generation $\mathbf{Z}$.

Examining the engineering higher education is crucially important for a country and when more societies think together how to improve and keep up with the latest expectations of the industry, education and various partners it can be really flourishing for all actors.

\section{References}

[1] Brady S. How Generation Z is Changing the Rules in Future Visions: Understanding Generation Z. - 2019 - https://www.rga.com/futurevision/magazine/futurevisionunderstanding-generation- $z$

[2] Future of Jobs Reports, World Economic Forum, 2016 https://www.hrportal.hu/hr/ujelvarasok-a-munkavallalok-fele-a-jovo-munkaero-piacan-20160127.html

[3] Langdon D. et al. STEM: Good Jobs Now and for the Future. ESA Issue Brief \#03-11. July, 2011. https://files.eric.ed.gov/fulltext/ED522129.pdf?fbclid= IwAR24WKqOPYerEK_QNGR1kgGoi050sFXiZEjEibL8SGpTjRXaP69QgNOE3X8

[4] Nooan R. STEM Jobs: 2017 Update. U.S. Department of Commerce Economics and Statistics Administration Office of the Chief Economist $-2017-1-16 \quad$ pp. https://files.eric.ed.gov/fulltext/ED594354.pdf?fbclid= IwAROgpadWk5oe6jiRwlchvPCoF1EtfTI4dIOTRTtyDufiqcdzEdVq95-urow

[5] Racsko R. Digitális átállás az oktatásban in Iskolakultúra. - Veszprém, 2017 - 9-11 pp. - ISBN 9789636937874

[6] Tari A. Z generáció. - Tercium Kiadó: Budapest, 2011 - 61-104 pp.

[7] Wang X. Why Students Choose STEM Majors: Motivation, High School Learning, and Postsecondary Context of Support. American 
Educational Research Journal October 2013, Vol. 50, No. 5, pp. 10811121 DOI: 10.3102/0002831213488622 https://www.insidehighered.com/ sites/default/server_files/files/Wang\{\%\}20AERJ\{\%\}200ct\{\%\}202013.pdf?fbclid= IwAR2rWd3IpVTjLRiwgQixVo4F1xSz6AKN3KZXmYbINYgikGoivnbf18V6vfs 